\title{
MORTE E LITERATURA NA ESCRITURA DE YUKIO MISHIMA
}

\section{MUERTE Y LITERATURA EN LA ESCRITURA DE YUKIO MISHIMA}

\section{Rodrigo Michell Araujo"}

Resumo: Este artigo investiga a experiência da morte na escritura de Yukio Mishima. Tomamos como corpus de análise duas expressivas obras do escritor, Confissões de uma Máscara (1984) e O Tempo do Pavilhão Dourado (1988), e, a partir de um diálogo entre filosofia e literatura, argumenta-se que há na obra de Mishima um intenso embate entre tradição e modernidade, resultando em uma mescla de vida e morte sem hostilidades. Para isso, pomos as obras em contato com pensamentos como o do filósofo romeno Emil Cioran e com a analítica existencial do filósofo alemão Martin Heidegger, e dos entrecruzamentos justificamos um autor-samurai que escreve com a espada, configurando uma escritura que carrega a morte como exercício ético de liberdade.

Palavras-chave: Japão.Morte.Escritura.Ética.Liberdade.

Resumen: Este artículo investiga la experiencia de La muerte em la escritura de Yukio Mishima. Tomamos como corpus de análisis dos expresivas obras del autor, Confissões de uma Máscara (1984) e O Tempo do Pavilhão Dourado (1988), y a partir de un diálogo entre filosofia y literatura, argumentamos que hayenla obra de Mishima um intenso enfrentamiento entre tradición y modernidad y el resultado de la pugna es una mezcla de vida y muerte sin hostilidades. Para ello, ponemos las obras em contacto com pensamientos como el del filósofo rumano Emil Cioran y la analítica existencial del filósofo alemán Martin Heidegger, a través de cuyo encuentro justificamos un autor-samurai que escribe con la espada, una escritura que lleva consigo la muerte como ejercicio ético de libertad.

Palabras clave: Japón. Muerte.Escritura.Ética. Libertad.

\footnotetext{
* Mestrando em Letras pela Universidade Federal de Sergipe (UFS).Bolsista pela Fundação de Amparo à Pesquisa e à Inovação Tecnológica do Estado de Sergipe (FAPITEC-SE) e integrante do Grupo de Estudos em Filosofia e Literatura (GeFeLit-UFS). E-mail: rodrigo.literatura@gmail.com
} 


\section{TERRA Do POENTE}

Como abordar uma civilização tão distante geograficamente de nós, ocidentais, como a civilização japonesa? E qual o nosso interesse por um país que por muito tempo permaneceu fechado ao ocidentalismo, como o Japão? Terra do poente, de clãs, imperadores, guerreiros e camponeses, palco de lutas cruzando eras. Terra dos samurais e das gueixas que tanto dedilharam o imaginário ocidental pela beleza e bravura. Falar da cultura japonesa é falar de uma cultura imageticamente rica, profusa visual e gestualmente, o que ratifica nosso imaginário de país das exuberâncias e do fascínio. Esta imagem se fundamenta quando tratamos principalmente da arte nipônica, dos ricos detalhes de suas esculturas, da grandiosidade de seus templos, do simbólico de seu teatro Nô, do poético de seu cinema. Sua literatura não foge a esta regra, e, se nos reportamos à poesia, desde as composições tankas à difusão e popularidade dos haikais, vemos como ela capta as pujanças de um país complexo e delicado.

Muito se tentou e buscou traduzir a essência da alma japonesa, e, assim, criando um embate cultural muito próximo do que apregoou o psicanalista Erich Fromm (1976), o ocidente "lógico" aristotélico, de um lado, e o oriente "ilógico", de outro. Tratamos neste artigo de um peculiar escritor contemporâneo japonês que presenciou profundas mudanças socioeconômicas no país pós 1945, após o duro agosto em que a primeira bomba atômica incendiou as portas nipônicas fazendo expor a japonidade a esse Outro - embora o império japonês tenha sofrido mudanças já desde o século XIX com a "Restauração Meiji", quando se transferiu o poder do Período Edo para o Período Meiji, marcando a economia do país.

Yukio Mishima, pseudônimo do célebre escritor Kimitake Hiraoka, nascido em Tóquio em 1925, presencia uma intensa modernização de um país não meramente transformado, após a ocupação americana, mas, de fato, nas palavras do historiador Oliveira Lima (1997, p. 95), "adaptado". A própria obra de Oliveira Lima, No Japão, consagrada por seus admiradores - como Gilberto Freyre -, embora sendo uma "impressão" de um diplomata, traz muito da atmosfera política e social do país no redemoinho da adaptação, além daquilo que em si permaneceu intocado e inabalável: "a encantadora natureza nipônica, misto de grandiosidade e graciosidade" (LIMA, 1997, p. 99). É diante desta mista paisagem que Mishima tece uma literatura em que a base é palco de um confronto entre a tradição e o novo. O autor vê desaparecer na cultura nipônica a figura do samurai guerreiro do Império; amante das artes marciais e desde cedo esculpindo o corpo para tornar-se um grande samurai, uma tese que Mishima levou até o final da vida - para encarar a morte é preciso preparar e esculpir o corpo. O que vemos no escritor é justamente uma luta em defesa da tradição nipônica, em defesa da ética samurai, em defesa do sol poente no país que outrora tinha aprendido a harmonia entre vida e morte; uma partida contra a atmosfera melancólica, nas palavras do sociólogo Maurice Pinguet (1987, p. 220): 
"Dupla melancolia para quem compreendia que a civilização capaz de forjar tais homens [os samurais] também tinha morrido".

Embora grande conhecedor do Ocidente, como nos mostra seu biógrafo, o jornalista britânico Henry Scott Stokes (1986), e levando para sua literatura uma tonalidade ocidental - por exemplo, citações e pensamentos de filósofos ocidentais, justificando a grande fama que teve Yukio Mishima fora do Japão -, o projeto de vida do autor foi defender até o fim o espírito feudal do país: "Mishima parece partilhar da ilusão ocidental de que o Japão ainda é um país de samurais; claro que o espírito deles persiste, mas a parafernália não" (STOKES, 1986, p. 21). O que Stokes nos coloca, e o acompanhamos na colocação, é que a cultura é dinâmicae, em se tratando daquele país por muito enclausurado, uma figura feudal tenderia a ficar no imaginário. Mas é salutar preservar o imaginário não como uma “ilusão", erro de percepção, algo negativo, mas algo próximo daquilo que tratou Gilbert Durand (1982), um imaginário que transforma o real.

Deste modo, a partir de dois romances de destaque do autor, Confissões de uma Máscara (1984) e O Templo do Pavilhão Dourado (1988), investigamos como se configura essa atmosfera em suas obras e como não só Mishima, mas também seus personagens defendem uma ética guerreira do samurai, como ambos (e por isso suas obras tem um tom autobiográfico, ou autoficcional) partem em defesa do código Hagakure que, como diz o próprio Mishima em um manifesto, "é uma tentativa de curar o caráter pacífico da sociedade moderna com o po- deroso remédio da morte" (MISHIMA, 1987, p. 31). Com isso, na obra de Mishima há um intenso embate entre tradição e modernidade e o resultado é uma mescla de vida e morte sem hostilidades, um estar diante da morte e encará-la que tão bem os samurais e o velho Japão souberam lidar. É neste movimento que a escritura de Mishima carrega a morte em suas páginas.

Expliquemos: que o olhar que lançamos para o Oriente e para a literatura de Yukio Mishima não intente cair em uma etnografia do "outro exótico", campo de trabalho da antropologia. Nosso caminho crítico percorre alguns filósofos, não no intuito de que, na análise, estes se sobreponham à obra literária, mas que haja uma "aproximação compreensiva”, como diz o crítico literário paraense Benedito Nunes, em No tempo do niilismo e outros ensaios (1993, p. 82) - uma transa entre campos disciplinares, matéria a que Benedito Nunes se dedicou em toda sua crítica. É neste ponto de encontro entre Ocidente e Oriente que estabelecemos uma dialogação, no sentido heideggeriano, para fundamentar nossa análise crítica.

\section{Festim da MORTE \\ 2.1 Confissões}

Guevaras, Mishimas: mortos, somos invencíveis.

$\left(\right.$ LEMINSKI $^{1}$

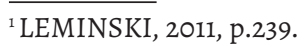


Jovens gladiadores postos a oferecer a vida, gritos agonizantes capazes de provocar até o mais pífio sentimento de tristeza, banhos de sangue, adagas, mais ainda: uma longa mesa sob uma toalha de um branco sublime, candelabros elegantes, pratos postos. Banquete fúnebre. Um dos cozinheiros se aproxima da mesa e anuncia que logo o jantar será servido. Mais gritos e gemidos, outro cozinheiro com um rapaz morto, corpo nu estendido ao chão. De rosto para cima ou para baixo, pergunta o cozinheiro? Outro cozinheiro com uma enorme travessa, ansiedade, corpo despido sobre a travessa. Começa o banquete, um garfo sobre o coração, jatos de sangue por todo lado, gozo e excitação em cada movimento.

Assim é descrita a cena do teatro de morte em Confissões de uma máscara(1984), em que o protagonista do romance, Koo-chan, fantasia seu desejo de morte. Escrito em forma de diário pelo narrador autodiegético, o romance é um córrego de sangue, sofrimento e orgasmos, um palco de crueldade aonde a morte chega até a ser posta como personagem na narrativa. Koo-chan a deseja como se esta assumisse um corpo desejante, como a morte em corpo de uma mulher vestida de branco e de seios à mostra no filme de Ingmar Bergman, $\mathrm{Na}$ presença de um palhaço (1997). Confissões pode ser chamado de romance autobiográfico por conter muitos passos do autor e de suas inquietações no protagonista ${ }^{2}$. Aflições, medos, delírios,

\footnotetext{
${ }^{2}$ Sobre obras autobiográficas ou "escritas de si", pode-se conferir o estudo de Philippe Lejeune, O pacto autobiográfico (2008), e um salutar estudo de Georges Gusdorf, Les écritures du moi, lignes de vie (1991).
}

frenesis, tudo em doses altas, em que viver é um dever, desagradável dever.

Seu percurso de inquietação e construção da máscara dá-se por três momentos: (i) memórias da infância, "preâmbulo de minha vida” (MISHIMA, 1984, p. 20), quando se dá sua inclinação "para a morte, a noite e o sangue" (Idem, p. 20) e quando "a relutante máscara começara a nascer" (Idem, p. 24); (ii) descoberta do prazer, uma urgência de começar a viver, e quando começa, a partir dos doze anos, a arquitetar seu teatro da morte; (iii) transição da adolescência para a fase adulta marcada pela guerra, momento de descoberta da morte como real objetivo de vida.

Nascido numa manhã de janeiro de 1925, Koo-chan passou a infância sendo criado pela avó, entre os odores da doença e da velhice. A ausência do belo escorre já pelas primeiras linhas - ausência que pode ser evidenciada também nas outras obras quando depara com um jovem sujo e abate-lhe o desejo de se transformar naquele moribundo, de ser ele. Logo cedo percebera que a vida não era contos de fadas. Mergulha em fantasias e lutas, além de despertar, ao mesmo tempo, o desejo carnal, embora sem compreender - primeiro, a atração pelas calças apertadas de um sujo transeunte, depois a atração pela figura heroica de um "homem" montado num cavalo como quem enfrentasse a morte, que depois iria descobrir ser Joana d'Arc. Das memórias da infância, podemos aproximar o protagonista, submerso às deficiências do mundo, àquilo que chamou o filósofo romeno Emil Cioran de origens do mal, ou princípios satânicos do 
sofrimento: "Comment combattre le malheur? Em nous combattrant nous-mêmes: en comprenant que la source du malheur se trouve em nous" (CIORAN, 1990, p. 119) ${ }^{3}$. Carrega, pois, em seu interior todos os sofrimentos do mundo, um combate com ele mesmo e além: combate com os sentidos da vida.

$O$ adeus à infância é expresso por dois caminhos: primeiro, pela sensação carnal e imersão na libido; segundo, que podemos dizer ser derivado do primeiro, pela denúncia do belo, direcionando-o a um esquartejamento - um écart èlement existencial cioraniano (CIORAN, 2004). O que chamamos de descoberta do prazer, sua primeira ejaculação, dá-se frente à imagem de São Sebastião, de Guido Reni, amarrado a uma árvore e com as mãos levantadas. A imagem daquele corpo nu, apenas coberto com um leve pano branco na região do órgão genital, além de flechas cravadas no corpo, foi para Koo-chan não só o marco de seu primeiro gozo, como foi também o preâmbulo da agonia de morte pelo martírio do corpo, dor magnífica e trágica. É como, digamos, se São Sebastião abrisse as portas para o gozo da dor, crueldade e prazer, no personagem (posteriormente, Mishima posaria nu na mesma posição de São Sebastião para uma fotografia de Kishin Shinoyama em 1970, pouco antes de sua morte). A outra imagem do prazer foi a de um colega de colégio, Omi, "primeiro amor que enfrentei na vida" (MISHIMA, 1984, p. 54), por quem teve vários momentos de ereção, que chamava de mau-hábito,

3 "Como lutar contra a desgraça? Lutando contra nós mesmos: compreendendo que a origem da desgraça se encontra em nosso interior". Tradução literal nossa. criando seu fetiche por axilas - o mesmo ideal de axilas de São Sebastião.

Mas é diante do espelho que Koo-chan depara com "o desgracioso reflexo do meu corpo nu" (Idem, p. 61), um confronto entre a beleza do Outro e a beleza de si mesmo. Duro reflexo que nos remonta à antológica cena do filme O sangue de um poeta (1930), de Jean Cocteau, que diz: "os espelhos deveriam pensar mais antes de refletir as imagens". Koo-chan conclui seu desgosto de si ao dizer: "Nunca você vai ser parecido com Omi" (MISHIMA, 1984, p. 61). A impossibilidade de ser parecido, ou ser ele, remonta-nos à ideia de desprezo de si de Cioran quando constata, em sua obra Suslescimesdudésespoir (1990, p. 99), que "Seul l'homme est capable de tant de mépris de soi"n. O desprezo de si é um passo que põe frente a frente o homem com a miséria da humanidade, sendo a máxima do pensamento do filósofo pessimista (1990, p. 100): "éternelle est la misère de l'humanitér. Nostálgico, saturado de si, constata-se aquilo que disse Cioran: tudo é poeira. E mais: tudo é nostalgia. Se a máxima do filósofo é que "Je suis mécontent de tout"(Idem, p. 81) ${ }^{6}$, será Koo-chan a concluir:

Estava saturado de mim mesmo e, apesar da minha castidade, destruindo o meu corpo. Pensara que com "seriedade" (que pensamento tocante!) eu também poderia escapar à minha condição infantil. Era como se eu ainda não tivesse percebido

\footnotetext{
4 "Somente o ser humano é capaz de tanto desprezo de si mesmo". Grifo do autor.

5 "Eterna é a miséria da humanidade".

6 "Tudo me deixa insatisfeito".
} 
que aquilo com que estava enojando agora era meu verdadeiro eu, era claramente uma parte de minha vida. (MISHIMA, 1984, p. 73).

Desta transição, entre a fase da infância e a fase adulta, podemos chamar de movimento de êxtase: de morte e de erotismo. Do sexo à morte, do sangue à carnificina, neste movimento Koo-chan é puro impulso. E o êxtase atinge os cumes quando os mundos exterior e interior se mesclam neste movimento - o que aproxima a saturação do protagonista da insatisfação cioraniana. E só mesmo nos cumes deste movimento que podemos extrair a máxima apontada por Darci Kusano (2006, p. 424): “êxtase da morte com a consumação do êxtase erótico”.

Da adolescência para a fase adulta, isto é, dos dezessete aos vinte e um anos, dois momentos marcam a exegese: a entrada na universidade para o curso de direito, um ano antes do final da guerra, em 1944, e a convocação para o serviço militar em uma fábrica de aviões já no último ano da guerra. Neste período, com a guerra, aviões e bombas como pano de fundo, é que se manifesta o maior sentimento trágico na narrativa, alcançando a morte seu ponto alto. O Japão ameaçado começara a provocar mudanças na sociedade, se o amanhã era mesmo incerto, a luz direcionava para o palco do presente, presente absoluto. Uma casa fechada, sob ameaça de ter as portas forjadas, um ovo prestes a quebrar: a vida foi algo que pudesse ser questionado, repensado, inquietações nipônicas muito bem derramadas pelas páginas do romance, no seguinte trecho:
Nessa época aprendi a beber e a fumar. Isso quer dizer que aprendi a fazer de conta que fumava e bebia. A guerra produzira uma maturidade estranhamente sentimental em nós. Fez que pensássemos na vida como algo que terminaria abruptamente pelos vinte anos; jamais considerávamos sequer a possibilidade de haver alguma coisa além daqueles poucos anos remanescentes. A vida nos surpreendeu como sendo uma coisa estranhamente volátil. (MISHIMA, 1984, p. 86).

A rápida permanência nos bancos da universidade dá-se por conta dos frequentes ataques aéreos, adiantando o exame físico no serviço militar e, com a classificação de apto para o serviço, o chamado para o trabalho na fábrica de aviões. Éa partir deste momento que aflora o sentimento e a experiência da morte, ou, de acordo com o personagem, finalidade da morte. Koo-chan espera por ela, "ansiava impacientemente pela morte com uma doce expectativa" (Idem, p. 93), deseja-a assim como Cioran a admirava num movimento de êxtase. Podemos dizer que o protagonista concorda com o pensamento de Cioran de que“l'une dês plus grandes illusions consiste à oublier que lavie est captive de lamort" (1990, p. 28)7. Esperar as bombas caírem e incendiarem tudo, para que reste nada mais que ruínas, fogo purificador, pois só pela destruição do mundo poderia destruir-se, negar-se rumo ao nada, "eu suspirava pela grande sensação de alívio que a morte certamente traria se apenas, como um lutador, eu pudesse

\footnotetext{
7 "Uma das grandes ilusões consistem em esquecer que a vida é seduzida pela morte”.
} 
arrancar o pesado fardo da vida sobre os ombros" (MISHIMA, 1984, p. 93). Eis sua doutrina da morte. Foi durante uma volta para casa, devido a um mal-estar, causandolhe uma febre, que o protagonista, olhando o mundo exterior pela janela do trem, pensou na completa destruição pela guerra, "fechava os olhos e imaginava uma cena em que toda a minha família era aniquilada num ataque aéreo" (Idem, p. 100). Eis, assim, seu maior desejo:

$O$ que eu queria era morrer entre estranhos, tranquilo, sob um céu sem nuvens. Entretanto, meu desejo diferia dos sentimentos daquele grego antigo que queria morrer sob o sol brilhante. O que eu queria era algum suicídio natural, espontâneo. Queria uma morte como a de uma raposa, ainda não muito versada em astúcia, que caminha descuidadamente por uma vereda na montanha e é atingida por um caçador devido à sua própria estupidez... (Idem, p. 100).

No apocalíptico ano de 1945 o Japão mergulhou em chamas, "o céu ficou vermelho-vivo" (Idem, p. 114), uma festa de destruição e morte. É neste ano que o protagonista fica face a face com a carnificina resultante dos bombardeios aéreos; dá-se neste momento aquilo que Darci Kusano (2006, p. 466) chamou de "estética da decadência". Em uma de suas voltas à fábrica, depara com vítimas do ataque, corpos espalhados no chão com os olhos vazios que nada veem; mães, filhos, uma fotografia da agonia. Apesar disso, confessa Koo-chan ter sido "encorajado e fortalecido por aquele desfile de miséria” (MISHIMA,
1984, p. 115). O impulso pelo grotesco e pelo sangue, isto é, pela carnificina, denuncia não apenas a ausência do belo, mas também direciona-nos para a tese de que "a beleza estaria associada à destruição e morte. [Isto é] a beleza só teria existência através da ruína e morte" (KUSANO, 2006, p. 467). Logo, seguindo a tese salutar apontada por Kusano, podemos concluir que a estética da decadência e da morte, em Confissões, dá-se pela tríade beleza-ruína-morte.

Pouco a pouco o desejo de nulidade o inflama como um incêndio interior nos alicerces da existência e que, somado ao incêndio exterior, o faz elaborar a tese de que "era na morte que eu havia encontrado meu real objetivo na vida" (MISHIMA, 1984, p. 131). Mergulhado na fantasia e no delírio, sonhava em apagar-se: "eu estava esperando [...] que durante aquele mês os americanos desembarcassem na baía $S$, e [...] que uma bomba monstruosa, como ninguém jamais imaginara, me matasse, não importa onde eu estivesse abrigado..." (Idem, p. 142). Mesmo contemplando a ideia de suicídio, não haveria motivo para o ato com a morte dançando tão próxima de si.

O desfecho do protagonista Koo-chan é a sensação do fracasso, da incapacidade. "Eu estava completamente exausto. No entanto, algum gatilho ainda estava adicionado na minha mente" (Idem, p. 180-181). Havia ainda um último gatilho, já que nenhuma bomba o atingiu como compulsivamente desejara. Se considerarmos que a obra seja autobiográfica, seria o seppuko o último ato de Koo-chan, assim como fez Mishima no quartel do Exército cravando a 
espada no ventre? Se, por um lado, o final da narrativa é aberto, para pensar com Umberto Eco (1991), e se, por outro, é o romance escrito em forma de diário, seria o protagonista o samurai que cometeu o harakiri(isto é, o suicídio, prática dos samurais)diante da derrota? Estas perguntas nos direcionam a confissões não apenas de uma máscara, mas também de uma filosofia negativa. Portanto, temos um personagem que carrega o peso do sofrimento, um romance que roça com a filosofia do pessimismo.

\subsection{O TEMPLO}

O desejo da morte, flatterlamort, também tem lugar privilegiado na narrativa do outro expressivo romance de Yukio Mishima, O Templo do Pavilhão Dourado (1988), que, também tendo a guerra como pano de fundo, apresenta um dos mais enigmáticos personagens da biografia do escritor: Mizoguchi. Outro romance escrito como diário de um personagem apocalíptico, a narrativa autodiegética penetra no descontentamento da realidade e fuga, que só se dará com o que chamaremos de arquitetura da destruição. Poderemos, assim, ler o romance por dois aspectos: antes e depois da presença do Templo Dourado na vida do protagonista.

Nascido em uma cidade litorânea do Japão, Mizoguchi narra, como Koo-chan, suas memórias da infância, que compreende o período antes de entrar para a vida monástica. Na infância, sempre ouvira do pai sobre o Templo Dourado como uma espécie de paraíso, isto é, neste período forma-se a ideia do protagonista acerca do Templo, um ideal de belo e sublime. A mãe era o oposto dessa ideia, tresloucada, maltrapilha, ausente de beleza e sendo de baixa condição social, mas, como gerado de um farrapo humano, o próprio Mizoguchi tinha sua deficiência no mundo: ser gago. Sua gagueira representa não só a dicotomia feio-belo como apresenta a atmosfera da monstruosidade que é sua vida já desde a infância. É lícito observar que o belo, para o protagonista, é o mundo exterior e o Templo Dourado, ou a ideia que tinha, como se a beleza fosse um objeto que se pudesse tocar; o feio era representado por ele e pela mãe, e mais: é como se o Templo Dourado fosse a mediação entre o belo e o feio. "Se a beleza realmente existia ali, isso significava que minha própria existência era uma coisa afastada da beleza" (MISHIMA, 1988, p. 22).

Conhecer o Templo e confrontar o objeto físico com a ideia que formara foi "inteiramente decepcionante" (Idem, p. 24), por ver apenas um simples prédio de três pavimentos. A ideia era mais sublime porque o protagonista amava o que podemos chamar de essência da coisa. A busca da beleza é digna de emoção como quando assistimos Mishima: uma vida em quatro capítulos (1985), a adaptação do Templo Dourado, além de outros textos de Mishima, feita por Paul Schrader, produção de Coppola e George Lucas, o ator diante do enorme templo, com uma memorável trilha sonora de Philip Glass. Mas é nessa busca que os pares antagônicos se mesclam na turva ótica do personagem:

O que é tão horrível em vísceras expostas? Por que cobrimos os olhos, aterrorizados, quando vemos as tripas 
de um ser humano? Por que as pessoas ficam tão chocadas ao ver o sangue jorrando? Por que os intestinos de um homem são feios? Não é, exatamente, da mesma qualidade da beleza de uma pele jovem e brilhante? (Idem, p. 57).

Questionar o papel do belo e do feio e levá-los ao limite era propício para um gago que vivia envolto de névoas, e é essa névoa hedionda que o liga ao Templo, esta é a incapacidade que tinha o primeiro amigo de Mizoguchi, Tsurukawa, de amar o Templo, pela ausência de tal ótica trágica do protagonista. A atmosfera monstruosa do personagem, como dito acima, irá se expandir em uma de suas lembranças da infância em que, num quarto onde constavam ele, o pai enfermo por tuberculose, a mãe e um parente que acabara de chegar, Mizoguchi presencia a traição da mãe com aquele homem desconhecido, bem aos olhos do marido enfermo, que, mesmo moribundo, tentou proteger os olhos do protagonista para não presenciar tal ato. Como se não bastasse, a morte posterior do pai alimentara um sentimento de vingança, impulsionando-o para a amargura e para a morte. Neste contexto, para atender o desejo do pai, decidirá pela vida monástica, ingressando no Templo Dourado.

A transição para o que chamamos de segunda fase dá-se por dois motivos: a entrada no monastério e a amizade com Kashiwagi. A guerra como pano de fundo aos poucos mostrava a derrota do Japão, mas, como o Templo situava-se em Kioto, não era um alvo de ataques aéreos, embora fosse de seu desejo a total destruição.
"Tornou-se meu sonho secreto que toda Kioto fosse envolvida em chamas" (Idem, p.46). Enquanto a capital do Japão ardia em chamas, Mizoguchi manifestava suas inquietações e seus pensamentos mais perversos, pois ele "era desesperadamente pobre de sentimentos humanos" (Idem, p.46). Já a ocupação americana, por exemplo, pode ser observada quando os oficiais americanos visitam o Templo, sendo Mizoguchi o guia daquilo que era um belo cartão postal para a ocupação.

Da presença no Templo e do contato com os ensinamentos do Zen budismo, Mizoguchi consegue ingressar na universidade, que terá papel importante para elaborar suas teses de vida, daí resultando sua amizade com o personagem Kashiwagi. Ambos irão compartilhar as deficiências da vida, motivo que os unirão fortemente, um por ser gago e o outro por ter os pés deformados - dois personagens que tinham um obstáculo na vida, sendo aquela névoa hedionda a condição mesma de vida. Da amizade e das partilhas que ambos vivem, Mizoguchi começa a elaborar sua tese da arquitetura da destruição, onde "viver e destruir eram a mesma coisa” (Idem, p.107): se o Templo Dourado lhe aparecia como uma mediação entre ele e o mundo, entre ele e a vida, era preciso destruí-lo. Destruir o Templo para poder viver será sua tese.

A ideia de incendiar o Temploestá muito próxima da concepção apocalíptica de Cioran sobre, a partir da concepção de solidão cósmica, incendiar o mundo, eliminar o Templo é, com um golpe cioraniano, eliminar a existência. Mizoguchi, aqui, 
pode concordar com a concepção de Cioran de que só se alcança o nada pela morte. Nadificar-se, de acordo com a máxima de Cioran (1990, p. 63): "Je voudrais exploser, couler, me décomposer's. Também concordaria Mishima com o nada heideggeriano? Quer dizer, um nada que é originário do Ser, pois se chega ao Ser pelo nada, bem como se chega ao nada pelo Ser. Que nada é esse que Heidegger fala? Seria o total aniquilamento, ou o filósofo alemão está dialogando com certa concepção do pensamento oriental de nada como vacuidade (sunyana)? Pela ótica heideggeriana, parece que derrubar o Templo é entregar-se ao nada, ou para usarmos um termo heideggeriano, suspender-se no nada'. da, bem como chega-se ao nada pelo Ser.Como Kioto parecia intacta aos bombardeios, e como nenhuma bomba iria cair sobre o Templo, como desejava Mizoguchi, o plano era incendiá-lo. "Coisas mortas como seres humanos não podem ser erradicados; coisas indestrutíveis como o Templo Dourado podem ser destruídas" (MISHIMA, 1988, p. 181).

Era preciso que o protagonista destruísseoTemplo(logo, seuidealdebeleza) para alcançar a vida, e consequentemente alcançar a Beleza, já que, segundo o

\footnotetext{
8 "Gostaria de me explodir, afundar, decompor".

9 Tese de Heidegger, em sua preleção Que é metafísica? (1989, p. 41), onde o suspender-se no nada é a possibilidade de liberdade e transcendência do ser. Só na ultrapassagem do ente o ser alcança o poder-ser livre e só na transcendência ele pode se encontrar com o ente que ele mesmo é. Heidegger só verá essa possibilidade de manifestação do nada pelo sentimento da angústia (tese de Ser e tempo) e pelo despertar do tédio, tonalidade afetiva fundamental do ser - tese de Os conceitos fundamentais da metafísica (2011b).
}

protagonista, "a beleza sempre me chega tarde" (Idem, p. 143) e que o Templo sempre "tenta me separar da vida" (Idem, p. 144). Mizoguchi (assim como o próprio Mishima) busca plotinianamente a Beleza suprema da vida, já que lhe falta o belo na vida. A vida constitui-se incompleta se não houver a busca do belo, como nos fala a filosofia antiga grego-pagã do alexandrino Plotino em seus tratados das Enéadas (1982); buscar o belo é um ofício da Alma para encher-se de virtude e retornar àquilo que é a unidade primeira geradora de todas as coisas, o Uno, o Bem supremo, o Absoluto. Essa é a busca do protagonista, um sentido, um significado da vida pelas trilhas da beleza.

Depois de derrubar o Templo, cogitava o nadificar-se, e isto se daria pelas vias do suicídio; tendo comprado veneno e um canivete "fiquei tão contente com eles que não pude deixar de me perguntar se não era assim que se sentia um homem que comprou uma casa nova e faz planos para o futuro" (MISHIMA, 1988, p. 222). Era preciso correr, correr para a morte, pois "correr leva ao fim e descansar também leva ao fim. A morte parece ser o descanso definitivo" (Idem, p. 228). Empilhando uns fardos de palha por cima de um colchão e um mosquiteiro diante de uma estátua do Templo, Mizoguchi executa seu plano incendiando aquele templo de uma beleza que lhe parecia insuperável, restava-lhe agora (re) nascer pelas chamas. Sentado, observando a dança do fogo, ironicamente acende um cigarro, confirmando sua doutrina de chamas. "Sentia-me como um homem que se senta para fumar depois 
de terminar um trabalho. Eu queria viver" (Idem, p. 242). Os verbos sentir e querer, no pretérito imperfeito, denunciam a ânsia do personagem pela realização do seu plano, de desmanchar-se pela destruição e pelo fogo. O final em aberto, assim como em Confissões, deixa a dúvida: será que Mizoguchi, assim como observado no desfecho de Koo-chan, também levou o harakiriao limite?

\section{Como escrever Com a espada}

Ao longo das mudanças socioeconômicas de um Japão abalado pela Segunda Guerra, YukioMishima lutou até o fim em defesa de uma "japonidade". Sintomático é seu discurso no quartel do Exército diante das tropas, um escritorsamurai que fez de sua brilhante espada instrumento de revolução e libertação ${ }^{10}$. Assim Mishima treinou seus personagens para o combate e para a morte. Por meio de Confissões e Templo, dois romances-diários, Mishima nos mostra como escrever com a espada a partir de sua estética da decadência e experiência da morte.

Como são incapazes de mudar a realidade em que vivem, a negação de si e do mundo será a ponte que liga os dois personagens, Koo-chan e Mizoguchi, que lutarão contra o mundo, arquitetando seus planos de destruição, em que a morte é o caminho. De uma aproximação de ambos os protagonistas, pode-se perceber: (i) a presença de um miserabilismo na exegese:

${ }^{10}$ Pode-se consultar a biografia de Mishima na primeira parte dedicada ao seu seppuko, seu ato "revolucionário" de suicídio (STOKES, 1986, p. 35-59). dois personagens que tinham, digamos, uma "deficiência" como condição de vida, um incapaz até de se olhar no espelho e suportar-se, outro marcado pela gaguez, o obstáculo que impedia de alcançar a vida, restando apenas a nulidade; (ii) um sentimento de destruição causado pela guerra como pano de fundo, ambos desejam a queda do mundo, a queda das bombas, ambos esboçam ruínas; (iii) o desejo da morte ou um exercício de admiração que flerta com as estruturas da vida, em que, como enfermos - cioranianamente falando -, experimentam o êxtase das profundidades últimas da vida rumo ao vazio absoluto, que só é possível pela morte, grande purificadora. Destes três movimentos pode-se chegar à tríade beleza-ruína-morte. A beleza é essa chave que falta para abrir a porta, porque se a beleza está ligada à ruína e à morte, como num filme sokuroviano" ambos os protagonistas vão lutar por uma bela morte, como se estivessem num palco na encenação de uma peça Nô.

Se reportarmo-nos a uma acepção do filósofo romeno Cioran, de que só "l'on $N E$ comprend La mort q'uen ressentant la vie comme une agonie prolongée" (CIORAN, 1990, p. 28$)^{12}$, podemos ver como as páginas da obra de Mishima são gritos agônicos. Os personagens mishimianos, sob outra ótica filosófica, trazem muito da analítica

\footnotetext{
11 Pode-se conferir um filme do cineasta russo AlexsandrSokurov, O Sol (2005), em que há uma explanação de como beleza-ruína-morte se relacionam, cabendo notartratar-se de um filme sobre o império japonês.

12 "Compreende-se a morte quem sente a vida como uma agonia prolongada”.
} 
existencial heideggeriana, e podemos aqui trazê-la em dois momentos da obra capital do filósofo alemão, Ser e tempo (2011a): primeiro, a partir da investigação dacompreensãodo ser, o Dasein (o ser-aí), na primeira parte da primeira seção do Livro I; o Dasein que é base constituinte do ser-no-mundo, "estrutura essencial do Dasein" (HEIDEGGER, 2011a, p. 102), como nos diz no parágrafo doze, Dasein que "está e é no mundo" (Idem, p. 158), de acordo com o parágrafo vinte e três do capítulo sobre a mundanidade do mundo. Segundo, o Dasein, enquanto ser-no-mundo, é ser-para-a-morte, como disserta Heidegger na segunda seção do Livro II em uma apreensão ontológica da morte. No parágrafo quarenta e nove, diz-nos Heidegger: "no sentido mais amplo, a morte é um fenômeno da vida. Deve-se entender vida como uma espécie de ser ao qual pertence um ser-no-mundo" (Idem, p. 321). O que o filósofo alemão nos diz é que a morte é uma possibilidade privilegiada do Dasein, do ser-aí, a morte pertence a este ser-aí, é iminente, está por vir. Os protagonistas mishimianos aqui analisados são seres-no-mundo e seres-para-a-morte, pois lhes configuram a possibilidade mais própria de Dasein, ou como diz Heidegger, "possibilidade existenciária" (Idem, p. 336). Personagens imersos no horizonte da angústia, sendo que, ainda no Livro II de Heidegger (Idem, p. 431), "a angústia cresce a partir do ser-no-mundo enquanto serlançado-para-a-morte". Imersos no nada do mundo, na insignificância do mundo, de acordo com a analítica existencial de Heidegger.
A obra de Mishima, além de flertar com a morte e nela se dissimular, carrega-a em suas páginas. Não por menos essa era a tese que o crítico literário Maurice Blanchot por muito perseguiu -morte e literatura como possibilidade: "somente a morte me permite agarrar o que quero alcançar; nas palavras, ela é a única possibilidade de seus sentidos. Sem a morte, tudo desmoronaria no absurdo e no nada" (BLANCHOT, 1997, p. 312). E se a vida é essa "que carrega a morte e nela se mantém" (Idem, 1997, p. 329), reafirmando nossa tese de uma mescla de vida e morte sem hostilidades, tanto a escritura carrega a morte quanto o autor se autodestrói na escritura. Experienciar a morte: desejá-la, encontrá-la. Uma transa. Um gozo. Êxtase.

É nas páginas incendiárias que Mishima apresenta sua morte-protesto, o grito de desespero que luta para dizer "não!". Assim como faz do harakiri sua morteprotesto, caminham seus personagens para a autoeliminação: dois personagenssamurais rumo à morte-protesto para dizer "basta!". Mishima preparou sua vida e seus personagens para isso. O poeta curitibano Paulo Leminski (discípulo de Mishima na veia literária), em Ensaios e Anseios Crípticos (2011, p. 230), diz do mestre: "Era a integridade de uma cultura que Mishima defendia quando abriu o ventre diante do Comandante do quartel de Tóquio, escrevendo com aço na pele de sua vida [...]: EU NÃO CONCORDO". Junto com o ideal Hagakure, Mishima levou às últimas consequências uma filosofia de vida, "sustentando que vida e morte são as duas 
faces de um escudo" (MISHIMA, 1987, p. 46). Ação e decisão, o caminho de Mishima é um caminho em busca do Belo e cuja finalidade é a boa morte, um caminho que segue as trilhas dos antigos samurais. E sua obra é um testemunho de liberdade e paixão. Liberdade para a morte. Sem dúvida, um artista em tempos de sol e aço.

\section{REFERÊNCIAS}

BLANCHOT, M. A parte do fogo. Trad. Ana Maria Scherer. Rio de Janeiro: Rocco, 1997.

CIORAN, E. Sur le cimes du désespoir.Trad. André Vornic. Paris: L'Herne, 1990.

Desgarradura. Barcelona: Tusquets, 2004.

DURAND, G. A imaginação simbólica. São Paulo: Cultrix, 1982.

ECO, U. Obra aberta. São Paulo: Perspectiva, 1991.

FROMM, E.; SUZUKI, D. T.; MARTINO, R. Zenbudismo e psicanálise. São Paulo: Cultrix, 1976.

GUSDORF, G. Les écritures du moi, lignes de vie.Paris: Odile Jacob, 1991.

HEIDEGGER, M. Que é metafísica?.Trad. Ernildo Stein. São Paulo: Nova Cultural, 1989 (Os Pensadores).

.Ser e tempo. 5.ed. Trad. Márcia de Sá Cavalcante. Petrópolis: Vozes, 2011a. 2 vols.

.Os conceitos fundamentais da metafísica: mundo, finitude, solidão. 2.ed. Trad. Marco Antonio Casanova. Rio de Janeiro: Forense Universitária, 2011b.

KUSANO, D. Yukio Mishima: o homem de teatro e de cinema. São Paulo: Perspectiva, 2006.
LEJEUNE, P. 0 pacto autobiográfico. Trad. Jovita Noronha, Maria Coimbra Guedes. Belo Horizonte: Editora UFMG, 2008.

LEMINSKI, P. Ensaios e anseios crípticos. Campinas: Editora da Unicamp, 2011.

LIMA, O. No Japão: impressões da terra e da gente. 3.ed. Rio de Janeiro: Topbooks, 1997.

MISHIMA, Y. Confissões de uma máscara. Trad. Manoel Paulo Ferreira. São Paulo: Círculo do Livro, 1984.

O Hagakure: a ética dos samurais. Trad. Waltensir Dutra. Rio de Janeiro: Rocco, 1987.

O templo do pavilhão dourado. Trad. Eliana Sabino. Rio de Janeiro: Rocco, 1988.

NUNES, B. No tempo do niilismo e outros ensaios. São Paulo: Ática, 1993.

PINGUET, M. A morte voluntária no Japão. Rio de Janeiro: Rocco, 1987.

PLOTINO. Enéada I-II (tomo I). Trad. Jésus Igal. Madrid: Gredos, 1982.

STOKES, H. S. A vida e a morte de Mishima. Trad. Milton Persson. Porto Alegre: L\&PM, 1986.

Recebido para publicação em 29 maio 2013 Aceito para publicação em 28 jul. 2013 